Rapp. Grønlands geol. Unders. 58, 63-74 (1973)

\title{
U-Pb AGE DETERMINATIONS ON ZIRCONS AND MONAZITES FROM A MIGMATITE AREA ON BJØRNEØER, SCORESBY SUND, EAST GREENLAND
}

\author{
A preliminary report
}

\section{F. Oberli and R. H. Steiger}

\section{Introduction}

During the 1969 geological expedition to Scoresby Sund, a small migmatite area on the south-west peninsula of island no. I of the Bjørneøer $\left(71^{\circ} 08^{\prime} 44^{\prime \prime} \mathrm{N} / 25^{\circ} 20^{\prime}\right.$ $56^{\prime \prime} \mathrm{W}$ - see fig. 1) was mapped and sampled in detail. More than $2000 \mathrm{~kg}$ of rock were collected for petrographic and isotope geochemical investigations to give an insight into the nature of rock-forming processes induced by high-grade regional metamorphism. The restriction to a very limited sampling area $(700 \mathrm{~m} \times 200 \mathrm{~m})$ provided rock samples which were subjected to very similar $P-T$ conditions for at least part of their history.

This report presents preliminary results obtained by the comparison of $\mathrm{U}-\mathrm{Pb}$ systematics of accessory minerals from various rock phases.

The first detailed geological mapping and petrographic investigation of the Bjørneøer (bear islands) was conducted by F. Kalsbeek in summer 1968 (Kalsbeek, 1969). The island group comprises crystalline rocks, chiefly migmatites, granites sensu lato and granitic gneisses. Common metasedimentary rocks such as biotite gneisses, mica schists, quarzites and some marbles, occur as larger coherent bodies, as paleosome of the migmatites and as schollen in the granites. Dioritic outcrops are common throughout the area; some of these bodies still exhibit igneous features, while others are strongly migmatised and often foliated. The contacts between migmatites, gneisses, granites and metasediments are generally transitional.

A group of intermediate to acidic rocks intrudes all the above mentioned rock units with sharp contacts. Most of them are rather fine-grained, reddish coloured granitic rocks which occur partly as flat-lying sheets as well as nearly vertical dykes with widths ranging from more than $100 \mathrm{~m}$ down to less than $1 \mathrm{~m}$. This group of 'younger granite dykes' (Kalsbeek, 1969) represents the last major rock generation of the area and is succeeded only by some small pegmatitic and aplitic veins and dykelets. 
The distinct foliation of the metasediments and the gneisses may be due to an early phase of isoclinal folding (Kalsbeek, 1969). With increasing degree of migmatisation the foliation pattern of the gneisses is destroyed and ultimately converted into massive rock of granitic composition containing occasional biotite-rich schlieren. Fault displacements have not been detected in the area, although the islands are dissected by a system of roughly N-S and E-W trending vertical crush zones.

From the presence of hypersthene, sillimanite, clinopyroxene, biotite, hornblende and cordierite in a few of the metasedimentary rocks, Kalsbeek (1969) concluded that an early metamorphism took place under low pressure granulite facies conditions. Henriksen \& Higgins (1969) report kyanite and sillimanite from similar metasedimentary rocks in the inner part of Nordvestfjord. They found a continuous transition from non-migmatised supracrustal rocks in the west (Krummedal supracrustal sequence) into highly migmatised gneisses in the east. The change from the paragenesis sillimanite + kyanite to sillimanite + cordierite (Henriksen \& Higgins, 1970) is explained by a decrease in pressure and a slight increase in temperature towards the Bjørneøer group.

\section{Description of the sampling area on the Bjørneøer}

The sampling area on island no. I of Bjørneøer lies astride the contact of a 1 to $2 \mathrm{~km}$ thick SE dipping granodioritic sheet (the 'grey granite' of Kalsbeek, 1969) and its overlying migmatitic rocks.

The migmatites consist mainly of fine-grained, garnet-bearing, biotite-plagioclase gneisses with a distinct foliation, which are veined by a network of granitic leucosome both concordant and discordant to the foliation. The leucosome is generally medium-grained (grain size ranging from about 1 to $5 \mathrm{~mm}$ ); locally, a more coarsegrained, pegmatoid phase of the leucosome may be observed. Apart from a few well preserved blocks of gneiss containing only traces of K-feldspar, the transition from the paleosome to the neosome of the migmatites is gradational.

Part of the neosome, in particular the thin layers parallel to the foliation of the metasediments, may have been produced by anatexis in situ, while the larger and more often discordant veins appear to have been injected from external sources. Kalsbeek (1969) estimates that $75 \%$ of the Bjørneøer migmatite is made up of granitic component. The dearth of residual material ('restite') led him to the conclusion that a major part of the granitic material was introduced from foreign sources.

Occasionally, calc-silicate boudins are found in the migmatites. These can be up to $20 \mathrm{~cm}$ thick and display a characteristic zoning with plagioclase (80-100\% An) in the core. Quartz and pyroxene (ferrosalite) occur as inclusions in the plagioclase, 
sphene and calcite occupying the interstices. In a transitional zone pyroxene is replaced by uralitic hornblende partly altered to actinolitic amphibole. The outer rim lying adjacent to the surrounding biotite-plagioclase gneisses consists of garnet and biotite. Some of the calc-silicate boudins are cut by shear zones invaded by granitic material. No reaction zoning was observed at the transected faces. Thus, it appears that the foliation and the metamorphism, which led to the zoning of the calc-silicate boudins are both older than a late stage of migmatisation.

The grey granite sheet varies in composition from a quartz diorite in the centre to a monzogranite at the contact with the migmatites (nomenclature after Streckeisen, 1967). This contact zone is transitional, ranging over a distance of some tens of metres to more than 100 metres. The numerous rotated schollen of migmatite in the grey granite show all grades from weak to strong granitisation. Away from the contact zone towards the centre of the grey granite the number of schollen markedly decreases. Over large areas of the grey granite, ghost remnants consisting of biotite schlieren are observed. Apart from these remnants, occasional blocks of amphibolitic composition as well as biotite-rich clinopyroxene bearing restites similar to those found in the migmatites can be seen.

The migmatite granite, which forms large coherent outcrops in the migmatites, consists of a more homogeneous and leucocratic type of granite than the greyish diatexitic neosome of the migmatites. The boundaries of these medium-grained, white to pink granites with the migmatite neosome are gradational over a range of generally less than $1 \mathrm{~m}$. This granite contains schlieren of biotite and amoeboid clusters of cordierite, probably relicts of absorbed metasediments. Garnet is not present in the homogeneous parts of the rock.

Post-kinematic, rather fine-grained, red, granitic dykes (the 'younger granites' of Kalsbeek, 1969) intruded the migmatites and granites after consolidation. The dykes cut the country rock with sharp contacts and contain hardly any inclusions. Apart from thin aplitic to pegmatitic dykelets, these granites are the youngest rock phase in the sampling area.

Evidence of an early phase of granulite facies metamorphism in the region, as suggested by Kalsbeek (1969) was not found in the small area studied for this report. As biotite, garnet, hornblende, cordierite and sillimanite were found in the migmatites and inhomogeneous parts and schollen of the grey granite, it is likely that the migmatisation took place chiefly under low pressure, upper amphibolite facies conditions. This conclusion was also drawn by Chadwick (1971), who describes suites of rocks in north-eastern Renland that are similar to the migmatites on the adjacent Bjørneøer. A minor occurrence of andalusite, in combination with sillimanite and cordierite in the migmatite of our sampling area, indicates a rather complicated polymetamorphic history for these rocks.

The relative age sequence of migmatites, migmatite granite and grey granite and the mode of emplacement of the granites is not clear. Unequivocal field evidence supporting intrusion of the granites into the migmatites is lacking, due to the fact 
that the migmatisation processes outlasted the emplacement of the grey granite and the migmatite granite. The numerous granitised schollen throughout the grey granite may suggest an anatectic origin of the rock, but the problem of the mass balance between paleosome and granitic neosome remains unsolved, if we have to assume a local source for the granite.

The results of the zircon work cast some doubt on any general assumption that the metamorphic processes, such as the foliation of the metasediments, the emplacement of the granites and the migmatisation, took place exclusively during the Caledonian orogenic cycle.

\section{Description of the rock samples and the zircon populations}

Four of the five rock samples referred to in this paper were collected from the small area on the south-west peninsula of island no. I of the Bjørneøer, whereas sample 101777 was collected on the east coast of the same island from the central part of the grey granite sheet $\left(71^{\circ} 10^{\prime} 11^{\prime \prime} \mathrm{N} / 25^{\circ} 19^{\prime} 07^{\prime \prime} \mathrm{W}\right)$. All the samples were drilled and blasted in order to avoid weathered rock material.

\section{Biotite-plagioclase gneiss, parent rock of the migmatite: GGU $166850 \mathrm{~A}$}

This rock sample was collected by B. T. Hansen in summer 1972 from an outcrop where rather well preserved metasediments occur. The sample contains about $20 \%$ of granitic neosome present in the form of veins. During crushing of the rock in the laboratory, care was taken to separate the rock into fragments comprising: (1) less than $10 \%$ leucosome (GGU $166850 \mathrm{~A}$, paleosome); (2) 10-90\% leucosome (GGU $166850 \mathrm{~B}$ ); and (3) more than $90 \%$ leucosome (GGU 166850 C). A typical fragment of the fine-grained, foliated, biotite-plagioclase gneiss (fraction A) comprises $41 \%$ plagioclase $\left(\mathrm{An}_{22}\right), 48 \%$ quartz and $10 \%$ biotite. In addition, some garnet, muscovite, chlorite and the accessories zircon, apatite, monazite and opaque minerals are present.

Over $50 \%$ of the zircons obtained from the paleosome rock fraction A are round to oval, showing faint signs of recrystallisation by development of new crystal faces. The rest of the zircon population ranges from very irregularly shaped grains to slightly rounded, euhedral crystals. A few grains show weak zoning, but all are translucent and slightly pink in colour. In contrast to the paleosome zircons, the zircons obtained from the leucosome (fraction $\mathrm{C}$, not yet analysed) display a clear trend towards better refaceting and development of eudhedral, prismatic morphology.

Grey granite from the centre of the granodioritic sheet: GGU 101777

The rock sample was collected by F. Kalsbeek in summer 1968 from a homogeneous phase of the grey granite on the east coast of island no. I of the Bjørneøer. 
The mode is $40 \%$ plagioclase $\left(\mathrm{An}_{35}\right), 18 \%$ microcline, $23 \%$ quartz and 17 $\%$ biotite. In addition, some pyroxene is present, often replaced by uralitic to actinolitic hornblende. Apatite, sphene, zircon and opaque minerals are found as accessories.

Except for a few rounded grains, the zircon population shows rather regular euhedral morphology, with slightly rounded pyramidal terminations. The larger grains often contain inclusions of small zircon (or apatite?) crystals and numerous cavities. The shape of the zircons varies from euhedral, long-prismatic to completely rounded crystals. We have to assume at least one major secondary phase of recrystallisation and new growth of zircon substance. The zircons are translucent, with a faint hyacinth tint.

Grey granite, leucocratic granitic variety near margin to migmatite: GGU 112603

The $130 \mathrm{~kg}$ rock sample was collected within $100 \mathrm{~m}$ from the contact to the migmatites. Great care was taken to obtain a homogeneous phase of the granite and to avoid any dykes. Nevertheless, some biotite lenses and cordierite clusters were detected in the rock sample after blasting, and were removed during crushing of the rock in the laboratory. The rock contains 35\% quartz, $32 \%$ plagioclase $\left(\mathrm{An}_{26-34}\right)$, $21 \%$ microcline, $9 \%$ biotite, $3 \%$ muscovite, some cordierite and the accessories zircon, monazite, apatite, allanite and opaque minerals.

The zircon morphology ranges from roundish grains to long-prismatic zircons. Nearly all the zircons show clear refaceting; other, typical recrystallisation phenomena are growth of pyramidal terminations over rounded grains. Apart from the fact that these zircons contain less inclusions than the zircons from the central part of the grey granite (GGU 101777) they occupy a somewhat intermediate position between the zircon population found in the centre of the granite and that of the biotite-plagioclase gneiss (paleosome of migmatite, GGU $166850 \mathrm{~A}$ ). The concentration of zoned zircons is somewhat higher than that found in the zircons from the centre of the grey granite sheet and is comparable to the paleosome sample. The zircons are translucent and of a faint hyacinth hue.

\section{Migmatite granite: GGU 112601}

A $130 \mathrm{~kg}$ sample was taken from a homogeneous outcrop of the white leucocratic variety of the migmatite granite, with the precaution of avoiding country rock. The mode of the rock is characterised by $34 \%$ microcline, $28 \%$ plagioclase $\left(A n_{21-25}\right), 33 \%$ quartz, $4 \%$ biotite and $1 \%$ muscovite. Some clusters of cordierite and accessories such as apatite, zircon and opaque minerals are also present.

In contrast to the zircons from the other four rock samples, about $90 \%$ of the migmatite granite zircons show strong zonation. Commonly, the zircons are euhedral and rather long-prismatic. Some of the few rounded zircons show cores without zoning and are mantled by zoned zircon substance, which tends to develop sharp pyramidal terminations. A few zircons free of zoning closely resemble the 
zircons of the biotite-plagioclase gneiss and may be simply admixtures from country rock. The colour of the zircons is generally faintly hyacinthine. Translucence can be slightly reduced by zoning.

Young granite dyke: GGU 112665

$160 \mathrm{~kg}$ of sample were collected from a $3 \mathrm{~m}$ thick fine-grained, reddish, granitic dyke. No traces of inclusions were detected. The rock consists of $33 \%$ quartz, 20 $\%$ plagioclase $\left(\mathrm{An}_{12-21}\right), 41 \%$ microcline, $3 \%$ biotite and $1 \%$ muscovite. Accessories are zircon, monazite, apatite and opaque minerals.

The zircons of the young granite dyke show the characteristics of zircons from unmetamorphosed intrusive rocks. They are generally long-prismatic with sharp edges and pointed pyramidal terminations. Some of the grains contain several small, prismatic, zircon-shaped inclusions, but most are homogeneous and waterclear. The presence of a few zoned crystals in the population may be due to admixture of wall rock zircons. The zircons range from colourless to slightly pink.

\section{Results and discussion of U-Pb analyses}

The zircon concentrates obtained from the rock samples were first sieved into varying grain sizes and subsequently split into fractions of different magnetic susceptibility. Most of the zircons were analysed for U-Pb using the new hydrothermal HF-dissolution method of Krogh (1973), which allows analyses of zircon fractions weighing less than $10 \mathrm{mg}$.

In order to check the analytical reproducibility, two splits from the intermediate magnetic zircon fraction of rock sample GGU 101777 and three splits from the intermediate magnetic and grain size fraction of sample GGU 112603 (fraction A) were analysed, using different spikes and methods. The differences between the extreme results were less than $0.5 \%$ for the ${ }^{207} \mathrm{~Pb} /{ }^{200} \mathrm{~Pb}$ and less than $0.9 \%$ for the $\mathrm{U}-\mathrm{Pb}$ ratios.

The $\mathrm{U}-\mathrm{Pb}$ ratios of 16 zircon and 4 monazite analyses from the five rock samples are plotted on a concordia diagram (fig. 13).

Monazites from the leucocratic variety of the grey granite (GGU 112603) and from the young granite dyke (GGU 112665)

As the zircon data show a rather complex pattern on the concordia diagram, it is practical to discuss the monazite ages first. All the monazites analysed yielded near-concordant $\mathrm{U}-\mathrm{Pb}$ ages, i. e. their respective ${ }^{206} \mathrm{~Pb} / 238 \mathrm{U},{ }^{207} \mathrm{~Pb} / 235 \mathrm{U}$ and ${ }^{207} \mathrm{~Pb} / 206 \mathrm{~Pb}$ ages lie within a narrow range. Equal $\mathrm{U}-\mathrm{Pb}$ ages would be a consequence of closed system behaviour of the mineral with respect to $\mathrm{U}$ and $\mathrm{Pb}$ after crystallisation or recrystallisation. The data points for concordant minerals on a concordia diagram $\left({ }^{206} \mathrm{~Pb} /{ }^{238} \mathrm{U}\right.$ vs. ${ }^{207} \mathrm{~Pb} /{ }^{235} \mathrm{U}$ diagram) plot on the concordia 


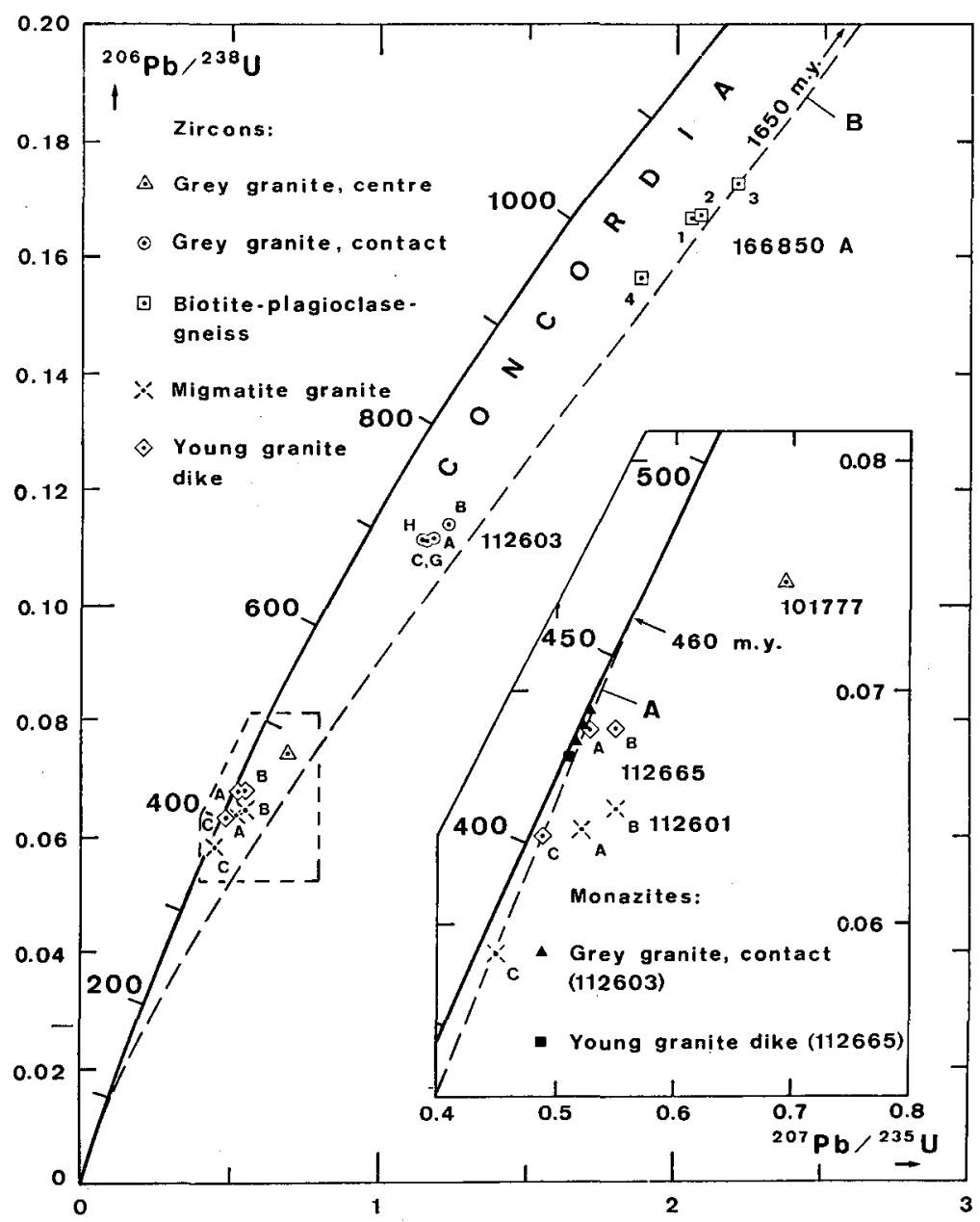

Fig. 13. Concordia diagram for zircons and monazites from island no. I of the Bjфrneфer, Scoresby Sund. The inset figure shows an enlarged section between 350 and $500 \mathrm{~m}$. y. of the main diagram with additional data points for monazites (solid symbols) and a continuous $\mathbf{P b}$ diffusion curve of $460 \mathrm{~m}$. y. (labelled A). Open symbols represent the zircon data points for different magnetic and grain-size fractions of the zircon concentrates obtained from five single-block rock samples. The six-digit-numbers refer to the GGU sample numbers; the individual zircon fractions are marked with smaller letters and numbers. Curve $B$ is a continuous diffusion curve for a primary crystallisation age of $1650 \mathrm{~m} . \mathrm{y}$. $\lambda{ }^{238} \mathrm{U}=1.5369 \times 10^{-10} \mathrm{y}^{-1}, \lambda{ }^{235} \mathrm{U}=9.7216 \times 10^{-10} \mathrm{y}^{-1}$

curve. As is the case for the sphenes (Tilton \& Grünenfelder, 1968) it appears that the monazites react more distinctly to metamorphic events than zircons. We have to assume that the monazites from Bjørneøer were formed during the last major metamorphic event (Köppel \& Grünenfelder, 1971). 
Three monazite fractions obtained from the leucocratic variety of the grey granite (GGU 112603) and one monazite fraction from the young granite dyke (GGU 112665 ) yielded ${ }^{207} \mathrm{~Pb} / 206 \mathrm{~Pb}$ ages of $445 \pm 10 \mathrm{~m}$. $\mathrm{y}$. The small discordance of the respective $\mathrm{U}-\mathrm{Pb}$ ratios shown on the concordia plot may be due to $\mathrm{Pb}$ loss during acid wash treatment of the monazites in the laboratory; thus, the ${ }^{207} \mathrm{~Pb}$ / ${ }^{206} \mathrm{~Pb}$ ages appear to represent the true ages for the closing of the U-Pb system in the monazites. The monazite age of the dyke is equal to or lower than the age of intrusion of the dyke. Since the dyke intruded into already consolidated migmatite and grey granite, the monazite age $(445 \mathrm{~m}$. y.) of the grey granite - being identical with the monazite age of the dyke - must represent a cooling age.

\section{Zircons from the young granite dyke: GGU 112665}

The three zircon fractions analysed from the young granite dyke are: (A) intermediate magnetic, with grain size ranging from 45 to $75 \mu$; (B) non-magnetic with grain size between 90 and $175 \mu$; (C) magnetic, finer than $45 \mu$. The zircons are slightly discordant, but do not display the usual straight-line pattern, as would be inferred from an episodic lead loss model (Wetherill, 1956) assuming Caledonian crystallisation of the zircons and $\mathrm{Pb}$ loss during recent uplift and erosion of the area. Neither does a continuous $\mathrm{Pb}$ diffusion model explain the particular zircon pattern. The fact that the coarse-grained fraction $B$ plots to the right side of the intermediate fraction $\mathrm{A}$, indicates an admixture of an older $\mathrm{Pb}$ component. This older $\mathrm{Pb}$ component may have been incorporated into the zircon population of the dyke by admixture of wall rock zircons. An alternative explanation for the relative 'offline' position of data point $B$ would imply a palingenetic origin of the young granite rock during the Caledonian orogeny, whereby zircons with incomplete $\mathbf{P b}$ loss were mixed with completely reset or newly formed zircons.

A maximum age for the formation of the dyke rock can be derived by construction of a continuous $\mathrm{Pb}$ diffusion curve (Tilton, 1960) through the data point of fraction $\mathrm{C}$ (curve $\mathrm{A}$, fig. 13) which lies closest to the concordia curve and thus shows the lowest ${ }^{207} \mathrm{~Pb} / 206 \mathrm{~Pb}$ age. The upper intersection of this curve with the concordia curve yields an age of $460 \pm 15 \mathrm{~m}$. y. for the primary crystallisation of the zircon population. The intrusion of the dyke and the cooling of the area coincide closely in time and set a lower limit for the climax of the Caledonian orogeny.

\section{Zircons of the biotite-plagioclase gneiss, paleosome of the migmatite:} GGU 166850 A

The following four zircon fractions of the biotite-plagioclase gneiss were analysed: representative split of the bulk sample (fraction 1); fraction between 90 and $100 \mu$ (fraction 2); non-magnetic fraction, 75-90 $\mu$ (fraction 3) and magnetic fraction, $30-40 \mu$ (fraction 4). These zircon fractions show the highest apparent ${ }^{207} \mathrm{~Pb} i$ ${ }^{206} \mathrm{~Pb}$ and $\mathrm{U}-\mathrm{Pb}$ ages of all zircons analysed. The zircon data points clearly do not fit onto a straight line. As the rock is of metasedimentary parentage, the 
non-linearity could simply be due to the detrital and thus heterogenic origin of the zircons. A similar zircon pattern could also result from multiple episodic $\mathbf{P b}$ loss or U gain likely to occur in polymetamorphic rocks.

A lower age limit for the primary crystallisation of the oidest part of these zircons can be deduced from a continuous diffusion model. A diffusion curve based on the model of Tilton (1960) passing through data point 3, which has the highest ${ }^{207} \mathrm{~Pb} /{ }^{206} \mathrm{~Pb}$ age, extrapolates to an upper intersection with concordia that corresponds to about $1650 \mathrm{~m}$. y. (curve B on diagram). The zircon fractions 1, 2 and 4 plot off this diffusion curve in the direction of the concordia curve, and it is possible that one or more metamorphic events have affected them after their primary crystallisation. Such episodic $\mathrm{Pb}$ diffusion (or $\mathrm{U}$ gain) would be superimposed on the continuous diffusion pattern and cause the zircon points to shift to the left of a continuous diffusion curve which passes through the data point of primary crystallisation. Such a mechanism was proposed by Tilton (1960) and solved quantitatively by Wetherill (1963).

\section{Zircons from the centre of the grey granite sheet: GGU 101777}

The data point for the analysed, intermediate magnetic fraction plots between the $1650 \mathrm{~m}$. y. diffusion curve and the concordia curve. A preliminary minimum diffusion age of $1065 \mathrm{~m}$. y. obtained by the diffusion model of Tilton (1960) reveals a pre-Caledonian history for the major part of the zircon population of this grey granite sample. Solely on the basis of the present $\mathrm{U}-\mathrm{Pb}$ data it cannot be decided whether this age implies a pre-Caledonian age for the emplacement of the grey granite, or merely absorption of older rock material by anatexis.

Zircons from the leucocratic variety of the grey granite (contact zone): GGU 112603

The five zircon fractions analysed are (A) intermediate magnetic, 45-75 $\mu$; (B) non-magnetic, 75-103 $\mu$; (C, G, H) magnetic fractions between 30 and $45 \mu$. They show a very small spread. The bulk of the zircon points plot in an intermediate position between samples GGU 101777 and GGU $166850 \mathrm{~A}$. In combination with the intermediate morphological properties, the analytical data suggest that the zircons from the contact zone of the grey granite represent a mixture of paleosome-type zircons and zircons similar to those found in the central part of the grey granite sheet.

\section{Zircons from the migmatite granite: GGU 112601}

The zircons from the migmatite granite are (A) intermediate magnetic, 53-75; (B) non-magnetic, coarser than $75 \mu$; (C) magnetic, finer than $36 \mu$. They also do not plot on a straight line. Part of the zircon population may have crystallised or recrystallised during the Caledonian orogeny as indicated by the finest fraction $\mathrm{C}$, which plots close to the $460 \mathrm{~m}$. y. diffusion curve drawn through fraction $112665 \mathrm{C}$ 
of the young granite dyke. The coarser fractions may be contaminated by admixture of a pre-Caledonian zircon component. This could be caused either by absorption of country rock material or, assuming an anatectic origin of the migmatite granite, by incorporation of incompletely reset zircon crystals from the parent rock. An alternative interpretation is the assumption of a pre-Caledonian age for the intrusion of the migmatite granite.

\section{Summary and conclusions}

The age of $445 \pm 10 \mathrm{~m}$. y. obtained for the nearly concordant monazites from the leucocratic variety of the grey granite and from the young granite dyke indicates the end of the Caledonian high-grade metamorphism. As the maximum age for the finest zircon fraction (C) of the dyke is $460 \pm 15 \mathrm{~m}$. $\mathrm{y}$., the dyke must have intruded some 460 (zircon age) to $445 \mathrm{~m}$. y. (monazite age) ago. Thus, the dykes which intruded into fractures of the cooling country rock are closely related to the final stage of the Caledonian orogeny. A biotite $\mathrm{K} / \mathrm{Ar}$ age of $435 \pm 12 \mathrm{~m}$. y. obtained from an intrusive dioritic rock collected on the coast of Renland opposite Bjørneøer (Larsen, 1969), is compatible with the monazite age.

The oldest part of the zircon population from the biotite-plagioclase gneiss (GGU $166850 \mathrm{~A}$ ) yields a minimum age of $1650 \mathrm{~m}$. y. by the continuous diffusion $\mathrm{Pb}$ loss model of Tilton (1960). This suggests that these zircons were formed, or completely recrystallised, prior to this date. It is not known whether these crystallisation processes took place before or after the sedimentation of the source material of the biotite-plagioclase gneiss.

The apparent $\mathrm{U}-\mathrm{Pb}$ ages of the zircons from the two grey granite samples are significantly lower than the ages of the paleosome zircons; however, they reveal a pre-Caledonian history for the major part of the zircon population and thus for the grey granite rock as a whole. From a continuous diffusion curve a minimum age of $1065 \mathrm{~m}$. $\mathrm{y}$. is inferred for the primary crystallisation of the zircon fraction from the centre of the granodiorite sheet (GGU 101777). If the grey granite was formed during an event prior to $1065 \mathrm{~m}$. y., little can be said about its origin. On the other hand, if a Caledonian age of formation is postulated, part of the zircon population must be derived from an older rock component, which became incorporated in or transformed into the granodiorite by anatexis or metasomatism. The transformation hypothesis is supported by the hybrid character of the granodiorite and the striking similarity of both morphology and $U$ concentrations of the biotite-plagioclase gneiss zircons and grey granite zircons.

The leucocratic variety of the grey granite from the contact zone yielded zircons with higher apparent $\mathrm{U}-\mathrm{Pb}$ ages than the zircons from the centre of the grey granite. This difference can be explained by the assumption that a relatively high 
portion of the zircons has been derived from the numerous digested metasedimentary schollen found in the contact zone with the migmatite.

The zircons from the migmatite granite plot close to the Caledonian section of the concordia curve. They are clearly different to those zircons of the biotite-plagioclase gneiss (paleosome) and to the grey granite zircons. The $U$ concentrations of the migmatite granite zircons are higher by a factor of three than those of the rest of the zircon populations. Their marked zoning could be due to growth under disequilibrium conditions with the host rock phase. Such conditions are probably present in partial melts, where substantial changes in composition will occur during different stages of anatexis. Thus, in contrast to the grey granite, the very leucocratic migmatite granite may have been generated locally by rock fractionation processes due to partial melting at comparatively shallow depths. It is likely that these occurred during the Caledonian orogeny. The pre-Caledonian $\mathrm{Pb}$ component may have been contributed by incompletely reset zircons from the parent rock of the migmatite granite.

The new analytical technique of Krogh (1973) enabled us to analyse very small amounts of zircons with extreme physical properties. The resulting $\mathrm{U}-\mathrm{Pb}$ data for the Bjørneøer zircons scatter over an area, rather than forming a linear array on the concordia diagram. In this respect the present data differ significantly from the straight-line patterns generally obtained from cogenetic zircons in igneous rocks. Similar areal distributions have also been observed by Krogh \& Davis (1973). These authors noted that the $\mathrm{U}-\mathrm{Pb}$ data points were displaced towards the time of a metamorphic event and that the displacement was proportional to the size of the zircons. They also think that after and before this event the data points were displaced along another series of lines, crossing the earlier set at a high angle and thus resulting in an areal distribution of the U-Pb data.

In our opinion, the basic reason for the areal distribution of the zircon data lies in the combined effects of episodic $\mathrm{Pb}$ loss or $\mathrm{U}$ gain and continuous $\mathrm{Pb}$ loss. $\mathrm{A}$ numerical solution of this problem was given by Wetherill (1963, in particular, fig. 1). In the case of the Bjørneøer zircons, additional parameters such as mixing and multiple episodic events appear to be involved. The occurrence of discrete events in the time interval of 445 to $1650 \mathrm{~m}$. y. specified by this zircon study is indeed suggested by the work of Hansen and coworkers (1971, 1972 and this report).

\section{References}

Chadwick, B. 1971: Preliminary account of the geology of south-east Renland, Scoresby Sund, East Greenland. Rapp. Gronlands geol. Unders. 34, 32 pp.

Hansen, B. T. \& Steiger, R. H. 1971: The geochronology of the Scoresby Sund area. Progress report 1: Rb/Sr mineral ages. Rapp. Grønlands geol. Unders. 37, 55-57.

Hansen, B. T., Steiger, R. H. \& Henriksen, N. 1972: The geochronology of the Scoresby Sund 
area. Progress report 2: $\mathrm{Rb} / \mathrm{Sr}$ mineral ages. Rapp. Grønlands geol. Unders. 48, 105-107. Henriksen, N. \& Higgins, A.K. 1969: Preliminary results of mapping in the crystalline complex around Nordvestfjord, Scoresby Sund, East Greenland. Rapp. Grфnlands geol. Unders. 21, 5-20.

Henriksen, N. \& Higgins, A.K. 1970: Preliminary results of mapping in the crystalline complex of Renland, the southern Stauning Alper and south-west Liverpool Land, Scoresby Sund, East Greenland. Rapp. Gronlands geol. Unders. 30, 5-17.

Kalsbeek, F. 1969: Preliminary report on the geology of Bjørneøer, Scoresby Sund. Rapp. Grønlands geol. Unders. 26, $33 \mathrm{pp}$.

Köppel, V. \& Grünenfelder, M. 1971: A study of inherited and newly formed zircons from paragneisses and granitised sediments of the Strona-Ceneri-Zone (Southern Alps). Schweiz. miner. petrogr. Mitt. 51, 385-409.

Krogh, T.E. 1973: A low-contamination method for hydrothermal decomposition of zircon and extraction of $\mathrm{U}$ and $\mathrm{Pb}$ for isotopic age determinations. Geochim. cosmochim. Acta 37, 485-494.

Krogh, T. E. \& Davis, G. L. 1973: The effect of regional metamorphism on U-Pb systems in zircons and a comparison with $\mathrm{Rb}-\mathrm{Sr}$ systems in the same whole rock. Carnegie Inst. Year Book 71, 564-571.

Larsen, O. 1969: K/Ar age determinations. Rapp. Grønlands geol. Unders. 19, 62-67.

Streckeisen, A. L. 1967: Classification and nomenclature of igneous rocks (Final report of an inquiry). Neues $J b$. Miner. Abh. 107, 144-240.

Tilton, G. R. 1960: Volume diffusion as a mechanism for discordant lead ages. J. geophys. Res. 65, 2933-2945.

Tilton, G. R. \& Grünenfelder, M. 1968: Sphene, uranium-lead ages. Science, N. Y. 159, 14581461.

Wetherill, G. W. 1956: Discordant uranium-lead ages, 1. Trans. Am. geophys. Un. 37, 320-326.

Wetherill, G. W. 1963: Discordant uranium-lead ages, 2. Discordant ages resulting from diffusion of lead and uranium. J. geophys. Res. 68, 2957-2965. 